\title{
KESESUAIAN AKUNTANSI ZAKAT, INFAK DAN SEDEKAH DENGAN PSAK 109 BAZNAS KABUPATEN TULUNGAGUNG
}

\author{
Lantip Susilowati, Fatimatul Khofifa \\ Institut Agama Islam Negeri (IAIN) Tulungagung, Indonesia \\ lantip_susilowati@yahoo.co.id, khofifa43@gmail.com \\ https://doi.org/10.46367/jas.v4i2.246
}

Received: Oct 19, 2020 Revised: Nov 11, 2020 Accepted: Nov 19, 2020 Published: Dec 16, 2020

\begin{abstract}
The potential for receiving zakat, infaq and alms funds in Tulungagung is growing rapidly. This shows that the level of trust in the management of zakat, infaq and alms funds is quite high. This study aims to examine the suitability of the application of PSAK 109 in the National Zakat Agency Tulungagung Regency. The method used in this research is a descriptive qualitative approach. Sources of data used are interviews, observation and documentation. The results showed that the accounting treatment at National Zakat Agency Tulungagung Regency included the receipt and expenditure of zakat, infaq and alms which was recognized as the amount of cash received and disbursed, presented and disclosed on the financial statements. Recognition and measurement of accounting treatment at National Zakat Agency Tulungagung Regency are in accordance with PSAK 109, while its presentation and disclosure are not fully in accordance with PSAK 109. The main obstacle faced is the limited qualified human resources and still uses a manual system in making financial reports.
\end{abstract}

Keywords: Accounting Treatment, Zakat, Infaq, Alms, PSAK 109.

\begin{abstract}
ABSTRAK
Potensi penerimaan dana zakat, infak dan sedekah di Tulungagung berkembang pesat. Hal ini menunjukkan tingkat kepercayaan terhadap lembaga pengelolaan dana zakat, infak dan sedekah cukup tinggi. Penelitian ini bertujuan untuk meneliti kesesuaian aplikasi Pernyataan Standar Akuntansi Keuangan (PSAK) 109 di Badan Amil Zakat Nasional (BAZNAS) Kabupaten Tulungagung. Metode yang digunakan dalam penelitian ini adalah pendekatan kualitatif deskriptif. Sumber data yang digunakan adalah wawancara, observasi dan dokumentasi. Hasil penelitian menunjukkan bahwa perlakuan akuntansi pada BAZNAS Kabupaten Tulungagung meliputi penerimaaan dan pengeluaran dana zakat, infak dan sedekah (ZIS) yang diakui sebesar jumlah kas yang diterima dan dikeluarkan, disajikan dan diungkapkan dalam laporan keuangan. Pengakuan dan pengukuran perlakuan akuntansi pada BAZNAS Kabupaten Tulungagung telah sesuai PSAK 109, sedangkan untuk penyajian dan pengungkapannya belum sepenuhnya sesuai PSAK 109. Kendala utama yang dihadapi adalah terbatasnya sumber daya manusia yang mumpuni dan masih menggunakan sistem manual dalam pembuatan laporan keuangannya.
\end{abstract}

Kata Kunci: Perlakuan Akuntansi, Zakat, Infak, Sedekah, PSAK 109. 


\section{PENDAHULUAN}

Zakat merupakan kewajiban setiap muslim yang mampu dan menjadi bagian dari Rukun Islam. Zakat, infak dan sedekah yang dikeluarkan oleh umat agar tepat sasaran kepada pihak yang membutuhkan, maka diperlukan suatu lembaga yang menangani zakat, infak dan sedekah. Sesuai dengan PSAK 109, terdapat aspek yang perlu diketahui agar lembaga pengelola zakat dapat melanjutkan usaha dengan baik, perlu didukung dengan kemampuan manajemen maupun perlakuan akuntansi zakat, infak dan sedekah secara professional. Yang dimaksud dengan professional disini yakni jika pengelolaan zakat, infak dan sedekah sesuai dengan syariat Islam, amanah, kemanfaatan, keadilan, kepastian hukum, terintegritas dan akuntabilitas (Rahman 2015). Pengelolaan zakat, infak dan sedekah secara profesional salah satunya ditunjukkan dari bagaimana suatu lembaga menerapkan akuntansinya. Penerapan akuntansi yang baik dapat diketahui dari sistem perencanaan dan pengendalian yang terorganisir, serta pencatatan transaksi sampai dengan laporan keuangan yang memuat informasi relevan sebagai bentuk pertanggungjawaban kepada publik.

Tujuan utama ditunaikannya zakat adalah untuk mencapai dan meningkatkan kesejahteraan umat sehingga pengelolaan zakat tidak dapat dilakukan secara sembarangan melainkan harus sesuai syariat Islam dan aturanaturan yang berlaku (Anshori 2006, 12). Untuk mencapai semua tujuan baik dilaksanakannya zakat tentunya tidak luput dari peran serta instansi pengelola zakat, infak dan sedekah yaitu Badan Amil Zakat Nasional (BAZNAS) yang didirikan oleh pemerintah serta adanya Lembaga Amil Zakat Nasional (LAZNAS) yang didirikan oleh masyarakat dan disahkan oleh Pemerintah. Tabel 1 merupakan daftar lembaga pengelola zakat di Tulungagung yang telah diakui BAZNAS secara nasional.

Tabel 1 Lembaga Pengelola Zakat Di Tulungagung

\begin{tabular}{cll}
\hline No & \multicolumn{1}{c}{ Lembaga Pengelola Zakat } & \multicolumn{1}{c}{ Email } \\
\hline 1 & BAZNAS Kabupaten Tulungagung & baznaskab.tulungagung@ baznas.go.id \\
2 & LAZ Baitul Maal Hidayatullah Tulungagung & cs.tulungagung@bmh.or.id \\
3 & LAZ Yatim Mandiri Tulungagung & web@yatimmandiri.org \\
4 & LAZ Manajemen Infak Tulungagung & info@lmizakat.org \\
5 & LAZ Muhammadiyah Tulungagagung & lazizmutulungagung@gmail.com \\
\hline \multicolumn{2}{l}{ Sumber: $B A Z N A S$} &
\end{tabular}

BAZNAS Kabupaten Tulungagung memiliki program-program kemandirian dan pemberdayaan masyarakat. Laporan keuangannya sudah diaudit oleh Kantor Akuntan Publik Suprihadi dan Rekan yang terletak di Malang dan juga oleh Kantor Wilayah Kementerian Agama Provinsi Jawa Timur Bidang Penerangan Agama Islam, Zakat dan Wakaf. Dengan alasan ini BAZNAS Kabupaten Tulungagung sangat tepat untuk menjadi lokasi penelitian. BAZNAS Kabupaten Tulungagung memiliki nilai Indeks Zakat Nasional (IZN) tertinggi untuk wilayah Provinsi Jawa Timur. Hal tersebut membuktikan bahwa potensi pengelolaan zakat pada BAZNAS Kabupaten Tulungagung tergolong baik, yang mana mereka memiliki kinerja yang bagus walaupun masih memerlukan perbaikan, seperti yang terlihat pada Gambar 1 . 


\section{Gambar 1 Nilai IZN OPZ Di Provinsi Jawa Timur}

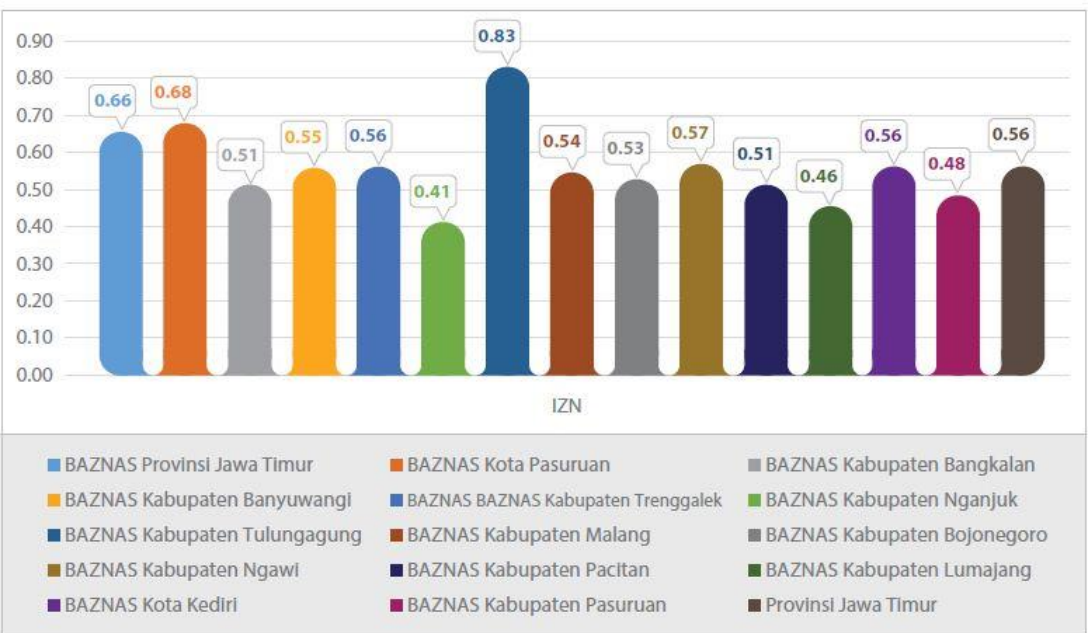

Sumber: Pusat Kajian Strategis BAZNAS Tahun 2019

Seiring berkembang pesatnya potensi pengelolaan zakat di BAZNAS Kabupaten Tulungagung tersebut, ada beberapa hal sensitif yang pertu diperhatikan yakni sistem akuntansi dan manajemen keuangan pada lembaga amil zakat. BAZNAS Kabupaten Tulungagung sebagai salah satu lembaga publik yang mengelola dana masyarakat, baiknya harus memiliki sistem akuntansi dan manajemen keuangan yang baik dan dapat menimbulkan manfaat bagi organisasi. Manfaat yang dimaksud adalah mewujudkan transparasi dan akuntabilitas sehingga berbagai laporan keuangan yang dibuat dapat akurat dan tepat waktu dalam perumusannya. Selain hal tersebut, keamanan dana akan lebih terjamin, karena adanya sistem kontrol yang jelas sehingga transaksi-transaksi lebih mudah ditelusuri sehingga seluruh proses keuangan benar-benar efektif dan efisien berlandaskan pada prinsip transparansi, akuntabilitas, pertanggungjawaban, independensi, dan keadilan dalam mencapai tujuan organisasi yang telah ditetapkan bersama (Rahim and Sahrullah 2017). Pengelolaan zakat perlu proses perencanaan dan pengorganisasian yang efektif dan efisien dalam setiap kegiatan pengakumulasian, penyaluran, serta pemanfaatan dana zakat (Wahab and Rahman 2011).

Laporan keuangan organisasi pengelola zakat seperti BAZNAS Kabupaten Tulungagung memang harus sesuai dengan tujuannya, yakni untuk menyajikan informasi bahwa dalam melakukan kegiatannya, BAZNAS Kabupaten Tulungagung sudah ataupun belum sesuai dengan ketentuan syariah. Laporan keuangan tersebut juga dapat digunakan sebagai acuan untuk menilai pelaksanaan tugas dan tanggungjawab BAZNAS tersebut. Aspek yang tidak kalah pentingnya dalam hal pengelolaan zakat, infak dan sedekah adalah pengawasan melalui proses auditing. Seluruh neraca keuangan BAZNAS Kabupaten Tulungagung harus terbuka untuk diaudit. Sebagai penerapan dari prinsip transparasi, diauditnya neraca keuangan baik oleh auditor internal maupun eksternal sudah menjadi suatu keniscayaan, maka dari itu untuk mendapatkan hasil audit yang baik, BAZNAS Kabupaten Tulungagung dalam membuat laporan keuangan hendaknya sesuai dengan aturan yang berlaku yaitu PSAK 109 mengenai akuntansi zakat, infak dan sedekah. 
Tabel 2 Rekapitulasi Kotak ZIS UPZ Masjid Besar Kecamatan

\begin{tabular}{lrrrr}
\hline \multirow{2}{*}{\multicolumn{1}{c}{ UPZ Masjid }} & \multicolumn{2}{c}{$\mathbf{2 0 1 8}$} & \multicolumn{2}{c}{$\mathbf{2 0 1 9}$} \\
\cline { 2 - 5 } & \multicolumn{1}{c}{ Infak } & Zakat & Infak & Zakat \\
\hline Masjid Al Islah (Ngantru) & 400.600 & - & 2.076 .300 & - \\
Masjid Baiturrohman (Kedungwaru) & 70.600 & - & 1.212 .000 & - \\
Masjid Agung Al-Munawar & 5.110 .000 & - & 32.172 .80 & 747.000 \\
Masjid Al-Falah (Ngunut) & 550.000 & - & 5.890 .000 & - \\
Masjid Al-Husna (Sumbergempol) & 3.950 .000 & - & 19.634 .000 & - \\
Masjid Al-Khoir (Rejotangan) & 337.000 & - & 380.000 & - \\
Masjid Al-Faqih (Kalidawir) & 697.000 & - & 2.735 .000 & - \\
Masjid Baiturrohman (Besuki) & - & - & 2.017 .500 & - \\
Majid Syariul Muttaqin (Boyolangu) & 121.000 & - & 4.596 .000 & - \\
Masjid Al-Barokah (Tanggunggunung) & 151.500 & - & 967.700 & - \\
Masjid Nurul Ridho (Kauman) & 1.028 .000 & - & 2.785 .000 & - \\
Masjid Sunan Kalijaga (Pagerwojo) & 2.370 .000 & - & 3.465 .000 & 2.972 .00 \\
Masjid Al-Hikmah (Gondang) & 151.000 & - & 1.346 .500 & - \\
\hline Jumlah & $\mathbf{1 4 . 9 4 8 . 7 0 0}$ & - & $\mathbf{7 9 . 2 7 7 . 8 0}$ & $\mathbf{3 . 7 1 9 . 0 0}$ \\
\hline Sumber: Dokumentasi BAZNAS Kabupaten Tulungagung & & &
\end{tabular}

Pada Tabel 2 dapat dilihat ada banyak Unit Pengumpul Zakat (UPZ) Masjid yang berada dibawah kelolaan BAZNAS Kabupaten Tulungagung. Hasil perolehan dana zakat dan infak/sedekah pada UPZ Masjid yang di data BAZNAS Kabupaten Tulungagung selama 2 periode mengalami peningkatan yang signifikan. Akan tetapi dalam praktiknya UPZ dibawah naungan BAZNAS Kabupaten Tulungaggung tersebut belum dapat melakukan pencatatan secara mandiri karena kebanyakan pengelola UPZ di Masjid tersebut adalah takmir masjid, dimana belum tentu mereka tersebut memenuhi syarat (Kurniasari 2011, 140) sebagai amil zakat yang paham akan tugasnya yakni bukan hanya sebagi pengumpul penyimpan dan penyalur zakat, melainkan juga sebagai pencatat (yang sesuai dengan PSAK 109). Amil yang profesional sangat berpengaruh terhadap efisiensi dan efektivitas penyaluran zakat. Adapun indikator amil yang profesional menurut beberapa peneliti adalah memahami: hukum zakat secara komprehensif dan mendasar; konsep dan praktik manajemen pada umumnya, dan manajemen zakat pada khususnya; konsep dasar akuntansi dan akuntabilitas (Abdullah et al. 2015; Muhamat et al. 2013; Wahab et al. 2017). Amil dikatakan profesional jika bersedia meluangkan waktunya secara penuh untuk fokus mengurusi zakat (full commitment).

Maka dari itu BAZNAS Kabupaten Tulungagung selaku lembaga yang menaunginya perlu mengadakan sosialisasi terkait pencatatan penerimaan dana zakat, infak dan sedekah tersebut. Penerapan PSAK 109 sangat penting karena digunakan untuk menyamakan laporan keuangan antar organisasi dan memudahkan proses pengauditan, sebab audit atas laporan keuangan BAZNAS Kabupaten Tulungagung ini merupakan bentuk transparasi kepada masyarakat luas karena dana yang dikumpulkan juga merupakan dana dari umat.

Berangkat dari penjelasan yang telah diuraikan, maka penelitian ini bertujuan untuk meneliti mengenai perlakuan akuntansi zakat, infak dan sedekah pada Badan Amil Zakat Nasional Kabupaten Tulungagung; kesesuaian perlakuan akuntansi zakat, infak dan sedekah pada Badan Amil Zakat Nasional Kabupaten Tulungagung dengan PSAK 109 dan juga meneliti kendala yang dihadapi oleh Badan Amil Zakat Nasional Kabupaten Tulungagung dalam menerapkan PSAK 109 beserta solusinya. 


\section{TELAAH LITERATUR}

Organisasi pengelola zakat merupakan salah satu entitas syariah disetiap wilayah baik di wilayah kabupaten maupun wilayah yang lebih luas. BAZNAS sebagai salah satu dari sekian banyak organisasi pengelola zakat pastinya memerlukan pertanggungjawaban dalam bentuk laporan keuangan yang harus sesuai pelaporan entitas syariah yaitu PSAK 109 (Fryanti 2018, 47). PSAK 109 wajib diterapkan oleh amil yang mendapat izin dari regulator, yaitu entitas pengelola zakat yang pembentukannya diatur oleh undang-undang (IAI 2011).

\section{Zakat, Infak dan Sedekah}

Zakat merupakan kewajiban yang dikenakan atas harta yang telah memenuhi persyaratan tertentu untuk diserahkan kepada penerima-penerima tertentu melalui petugas tertentu. Menurut PSAK nomor 109 zakat adalah harta yang wajib dikeluarkan oleh muzaki sesuai dengan ketentuan syariah untuk diberikan kepada yang berhak menerimanya (mustahik). Menurut UndangUndang Nomor 23 tahun 2011, bahwa zakat merupakan pranata keagamaan yang bertujuan untuk meningkatkan keadilan kesejahteraan masyarakat (Ritonga 2017).

Seiring dengan perkembangan kehidupan kaum muslimin di era modern saat ini, muncul berbagai macam masalah yang belum pernah kita jumpai dalam masa kehidupan Rasulullah, dimana masalah tersebut juga berkaitan dengan harta dan zakat dan akhirnya munculah zakat kontemporer. Adapun beberapa jenis objek zakat kontemporer yang muncul di tengah-tengah kehidupan kaum muslimin saat ini antara lain, zakat profesi, zakat tanah, zakat atas usaha pinatu/ laundry, serta berbagai zakat lainnya (Nurhayati et al. 2019, 39).

Infak berasal dari bahasa Arab anfaqa yang artinya mengeluarkan atau membelanjakan harta. Dari akar kata tersebut, istilah infak secara umum yaitu setiap mengeluarkan harta, baik untuk tujuan kebaikan maupun keburukan dikatakan infak. Secara terminologi syariah infak yaitu mengeluarkan sebagian dari harta untuk suatu kepentingan yang sesuai dengan ajaran islam (Nurhayati et al. 2019, 157). Sedekah memiliki dimensi yang sangat luas, tidak hanya berdimensi memberikan sesuatu dalam bentuk harta saja, tetapi dapat berupa berbuat kebajikan, baik untuk diri sendiri maupun untuk orang lain (Rahman 2015, 147). Berdasarkan Al-Quran Surat Al-Baqarah Ayat 215, dijelaskan bahwa dalam penyaluran infak yang didahulukan adalah orang tua, kemudian kerabat, dan seterusnya. Bahkan dapat diatasnamakan atau pahalanya dapat dialihkan pada orang tua yang sudah meninggal (Nurhayati et al. 2019, 160).

\section{Lembaga Pengelola Zakat}

Zakat merupakan ibadah yang sifatnya memiliki dimensi sosial kemanusiaan. Penyaluran zakat yang akuntanbel dapat dilakukan secara langsung atau melalui institusi amil zakat, baik berupa Badan Amil Zakat (BAZ) yang dikelola pemerintah maupun Lembaga Amil Zakat (LAZ) yang dikelola oleh pihak swasta. Pemahaman akuntabilitas dalam perspektif Islam adalah kepastian hubungan pengelola organisasi dengan pihak-pihak yang berkepentingan (stakeholder) untuk memperhatikan kepentingan mereka dalam bentuk tanggung jawab sosial dan moral (Muchlis and Sukirman 2015). Konsep akuntabilitas tidak hanya terbatas pada pertanggungjawaban finansial, melainkan kepada kemampuan 
pengelola untuk meningkatkan tanggung jawab mereka kepada lingkungan organisasi yang melingkupi masyarakat sekitarnya ataupun pemerintah, serta ketaatan kepada peraturan-peraturan yang terkait (Mansour et al. 2015).

Ada beberapa alasan pembayaran zakat sebaiknya melalui institusi atau lembaga pengelola zakat, yaitu dalam rangka menjamin ketaatan pembayaran; menghilangkan rasa rikuh dan canggung yang mungkin dialami oleh mustahik ketika berhubungan dengan muzaki; mengefisienkan dan mengefektifkan pengalokasian dana zakat; dan juga alasan caesoropapisme yang menyatakan ketidakterpisahan antara agama dan negara karena zakat termasuk urusan negara juga (Al Arif 2012, 396).

Badan Amil Zakat merupakan badan resmi dan satu-satunya yang dibentuk oleh pemerintah berdasarkan Keputusan Presiden RI No. 8 Tahun 2001 yang memiliki tugas dan fungsi menghimpun dan menyalurkan zakat, infak dan sedekah pada tingkat nasional (Presiden RI 2001). Lahirnya Undang-Undang nomor 232011 tentang pengelolaan zakat semakin mungukuhkan peran BAZNAS sebagai lembaga yang berwenang melakukan penglolaan zakat secara nasional. Dalam undang-undang tersebut, BAZNAS dinyatakan sebagai lembaga pemerintah nonstruktural yang bersifat mandiri dan bertanggung jawab kepada presiden. BAZNAS memiliki tugas untuk melakukan pengelolaan zakat secara nasional (Presiden RI 2011).

Dalam melaksanakan tugas dan fungsinya, BAZNAS provinsi atau BAZNAS kabupaten/kota dapat membentuk UPZ pada instansi pemerintah, badan usaha milik negara, badan usaha milik daerah, perusahaan swasta, dan perwakilan Republik Indonesia di luar negeri serta dapat membentuk UPZ pada tingkat kecamatan, kelurahan atau nama lainnya, dan tempat lainnya. Ketentuan lebih lanjut mengenai organisasi dan tata kerja BAZNAS provinsi dan BAZNAS kabupaten/kota diatur dalam Peraturan Pemerintah. Selain BAZNAS lembaga yang dapat menyelenggarakan pengelolaan zakat adalah LAZ (Lembaga Amil Zakat). Pembentukan LAZ wajib mendapatkan izin menteri atau pejabat yang ditunjuk oleh menteri (Presiden RI 2011).

\section{Perlakuan Akuntansi Zakat, Infak dan Sedekah PSAK 109}

Penerimaan zakat diakui pada saat kas atau aset non kas diterima. Zakat yang diterima dari muzaki diakui sebagai penambah zakat sebesar jumlah yang diterima jika dalam bentuk kas dan nilai wajar jika dalam bentuk non kas. Penentuan nilai wajar aset non kas yang diterima menggunakan harga pasar. Jika harga pasar tidak tersedia maka dapat menggunakan metode penentuan nilai wajar lainnya sesuai yang diatur dalam SAK yang relevan. Jika muzakki menentukan mustahik yang harus menerima penyaluran zakat melalui amil, maka tidak ada bagian amil atas zakat yang diterima. Amil dapat memperoleh ujrah atas kegiatan penyaluran tersebut. Ujrah ini berasal dari muzaki, di luar dana zakat. Ujrah tersebut diakui sebagai penambah dana amil (IAI 2019, 109.1).

Jika terjadi penurunan nilai aset zakat non kas, maka jumlah kerugian yang ditanggung diperlakukan sebagai pengurang dana zakat atau pengurang dana amil bergantung dari penyebab kerugian tersebut. Penurunan nilai aset zakat diakui sebagai pengurang dana zakat, jika terjadi tidak disebabkan oleh kelalaian amil, serta kerugian dan pengurang dana amil, jika disebabkan oleh kelalaian amil (IAI 2019, 109.2). Zakat yang disalurkan kepada mustahik, termasuk amil, diakui 
sebagai pengurang dana zakat sebesar jumlah yang diterima, jika dalam bentuk kas dan nilai wajar, jika dalam bentuk non kas (IAI 2019, 109.3).

Efektivitas dan efisiensi pengelolaan zakat bergantung pada profesionalisme amil. Dalam konteks ini amil berhak mengambil bagian dari zakat untuk menutup biaya operasioanl dalam rangka melaksanakan fungsinya sesuai dengan kaidah atau prinsip syariah dan tata kelola organisasi yang baik. Penentuan jumlah atau presentase bagian untuk masing-masing mustahik ditentukan oleh amil sesuai dengan prinsip syariah, kewajaran, etika, dan ketentuan yang berlaku yang dituangkan dalam kebijakan amil. Beban penghimpunan dan penyaluran harus diambil dari porsi amil. Amil dimungkinkan untuk meminjam dana zakat dalam rangka menghimpun zakat (IAI 2019, 109.4).

Penentuan nilai wajar aset non kas yang diterima menggunakan harga pasar. Jika harga pasar tidak tersedia, maka dapat menggunakan metode penentuan nilai wajar lainnya sesuai dengan SAK yang relevan. Infak/sedekah yang diterima dapat berupa kas atau aset non kas. Aset non kas dapat berupa aset lancar atau tidak lancar (IAI 2019, 109.4).

Penurunan nilai aset infak/sedekah tidak lancar diakui sebagai pengurang dana infak/sedekah, jika terjadi tidak disebabkan oleh kelalaian amil, serta diakui sebagai kerugian dan pengurang dana amil, jika disebabkan oleh kelalaian amil. Dalam hal amil menerima infak/sedekah dalam bentuk aset (non kas) tidak lancar yang dikelola oleh amil, maka aset tersebut harus dinilai sesuai dengan SAK yang relevan. Dana infak/sedekah sebelum disalurkan dapat dikelola dalam jangka waktu sementara untuk mendapatkan hasil yang optimal. Hasil dana pengelolaan diakui sebagai penambah dana infak/sedekah (IAI 2019, 109.5). Penyaluran dana infak/sedekah diakui sebagai pengurang dana infak/sedekah sebesar jumlah yang diserahkan, jika dalam bentuk kas dan sebesar nilai tercatat aset yang diserahkan, jika dalam bentuk aset nonkas (IAI 2019, 109.5).

Penyaluran infak/sedekah oleh amil kepada amil lain merupakan penyaluran yang mengurangi dana infak/sedekah jika amil tidak menerima kembali aset infak/sedekah yang disalurkan tersebut. Penyaluran infak/sedekah kepada penerima akhir dalam skema dana bergulir dicatat sebagai piutang, infak/sedekah bergulir dan tidak mengurangi dana infak/sedekah. Amil menyajikan dana zakat, dana infak/sedekah, dan dana amil secara terpisah dalam laporan posisi keuangan (IAI 2019, 109.5).

Amil harus mengungkapkan hal-hal berikut terkait dengan transaksi zakat, tetapi tidak terbatas pada (1) Kebijakan penyaluran zakat, seperti penentuan skala prioritas penyaluran, dan mustahik nonamil; (2) Kebijakan penyaluran zakat untuk amil dan mustahik non amil seperti persentase pembagian, alasan, dan konsistensi kebijakan; (3) Metode penentuan nilai wajar yang digunakan untuk penerimaan zakat berupa aset non kas; (4) Rincian jumlah penyaluran dana zakat untuk masing-masing mustahik; (5) Penggunaan dana zakat dalam bentuk aset kelolaan yang masih dikendalikan oleh amil atau pihak lain yang dikendalikan amil, jika ada, diungkapkan jumlah dan persentase terhadap seluruh penyaluran dana zakat serta alasannya; (6) Hubungan pihak-pihak berelasi antara amil dan mustahik meliputi sifat hubungan, jumlah dan jenis aset yang disalurkan, presentase dari setiap aset yang disalurkan tersebut dari total penyaluran zakat selama periode (IAI 2019, 109.5). 
Amil mengungkapkan hal-hal berikut terkait dengan transaksi infak/sedekah, tetapi tidak terbatas pada: (1) Kebijakan penyaluran infak/sedekah, seperti penentuan skala prioritas penyaluran infak/sedekah dan penerima infak/sedekah; (2) Kebijakan penyaluran infak/sedekah untuk amil dan nonamil, seperti presentase pembagian alasan, dan konsistensi kebijakan; (3) Metode penentuan nilai wajar yang digunakan untuk penerimaan infak/sedekah berupa aset nonkas; (4) Keberadaan dana infak/sedekah yang tidak langsung disalurkan tetapi dikelola terlebih dahulu, jika ada, diungkapkan jumlah dan persentase dari seluruh penerimaan infak/sedekah selama periode pelaporan serta alasannya (5) Hasil yang diperoleh dari pengelolaan yang dimaksud diungkapkan secara terpisah; (6) Penggunaan dana infak/sedekah menjadi aset kelolaan, jika ada, diungkapkan jumlah dan persentase terhadap seluruh penggunaan dana infak/sedekah serta alasannya; (7) Rincian dana infak/sedekah berdasarkan peruntukannya, terikat dan tidak terikat; (8) Hubungan pihak-pihak berelasi antara amil dengan penerima infak/sedekah yang meliputi sifat hubungan, jumlah dan jenis aset yang disalurkan, presentase dari setiap aset yang disalurkan tersebut dari total penyaluran infak/sedekah selama periode. Selain membuat pengungkapan di paragraf diatas, amil mengungkapkan hal-hal berikut: (a) Keberadaan dana nonhalal, jika ada, diungkapkan mengenai kebijakan atas penerimaan dan penyaluran dana, alasan, dan jumlahnya; (b) Kinerja amil atas penerimaan dan penyaluran dana zakat dan dana infak/sedekah (IAI 2019, 109.6).

\section{Laporan Keuangan Amil}

Laporan keuangan amil dibuat dengan mengikuti siklus akuntansi sebagaimana umumnya entitas usaha lain dalam menyusun laporan keuangan. Siklus akuntansi dimulai dengan adanya transaksi yang dibuktikan dengan dokumen pendukung. Berdasarkan dokumen pendukung tersebut maka dibuat jurnal transaksi dari tanggal, pertama sampai akhir bulan. Transaksi amil dibedakan menjadi transasksi penerimaan dan penyaluran dana zakat, penerimaan dan penyaluran dana infak, serta penerimaan dan penggunaan dana amil. Penerimaan dana zakat bisa amil peroleh dari entitas usaha syariah maupun individu muslim. Atas zakat ini amil akan mencatat sebagai kas dan penerimaan dana zakat.

Amil dapat menyalurkan dana infak/sedekah dengan klasifikasi penyaluran seperti penyaluran kepada mustahik sebagai distribusi dana infak/sedekah untuk keperluan konsumsi mustahik, penyaluran dana infak/sedekah untuk pengelola zakat, infak/sedekah (amil), dana infak/sedekah digunakan untuk dana bergulir, yang dipinjamkan untuk memberdayakan ekonomi umat, sehingga diperlakukan sebagai penyaluran, akan tetapi diperlakukan sebagai piutang infak/ sedekah bergulir, dan dana infak/ sedekah juga dapat disalurkan sebagai aset kelolaan, baik yang dikelola oleh amil sendiri maupun lembaga independen lain yang dipercayakan oleh amil (IAI 2019, 109.7).

Setelah amil mencatat seluruh transaksi yang terkait dengan zakat, infak/sedekah beik penerimaan maupun penyaluran, maka tahap berikutnya adalah memposting ke buku besar sehingga akan diperoleh saldo akhir akun tersebut. Setelah posting selesai, tahap berikutnya adalah pengikhtisaran yaitu dengan menyusun neraca saldo. Setelah itu tahap berikutnya adalah melakukan penyesuaian atas saldo pos-pos akun yang berada di neraca saldo. Kemudian 
membuat neraca saldo setelah penyesuaian disusun berdasarkan neraca saldo sebelum penyesuaian ditambah atau dikurangi angka penyesuaian nerdasarkan jurnal penyesuaian. Tahap selanjutnya adalah membuat neraca lajur guna memudahkan membuat laporan keuangan amil (Nurhayati et al. 2019, 165). Untuk laporan keuangan amil diatur dalam PSAK 101, terdiri dari: laporan posisi keuangan; laporan perubahan dana; laporan perubahan aset kelolaan; laporan arus kas; catatan atas laporan keuangan (IAI 2007).

\section{METODE PENELITIAN}

Penelitian ini menggunakan pendekatan kualitatif dengan jenis deskriptif dimana peneliti berusaha mengumpulkan fakta-fakta yang ada yang berkaitan dengan akuntansi zakat, infak dan sedekah yang berada di BAZNAS Kabupaten Tulungagung yang beralamat di jalan. Mayor Sujadi nomor 172 Jepun, Kecamatan Kedungwaru, Kabupaten Tulungagung, Jawa Timur. Teknik pengumpulan data pada penelitian ini menggunakan beberapa metode observasi, wawancara dan dokumentasi. Sumber data primer dalam penelitian ini adalah keterangan yang diberikan oleh informan (karyawan dan pihak pihak yang bersangkutan) melalui wawancara. Sumber data sekunder yang digunakan dalam penelitian ini adalah laporan keuangan BAZNAS Kabupaten Tulungagung Tahun 2019. Sedangkan analisis data dilakukan dengan reduksi data, penyajian data, penarikan kesimpulan dan verifikasi. Untuk melakukan pengecekan keabsahan temuan, peneliti menggunakan triangulasi sumber, yaitu dengan mengecek data yang diperoleh melalui tiga sumber.

\section{HASIL DAN PEMBAHASAN PENELITIAN}

\section{Perlakuan Akuntansi Zakat, Infak Dan Sedekah BAZNAS Kabupaten Tulungagung}

Perlakuan akuntansi ZIS di BAZNAS Kabupaten Tulungagung diawali dengan diterimanya transaksi masuk berupa dana zakat, infak dan sedekah dan transaksi keluar berupa penyaluran dana zakat, infak dan sedekah berdasarkan program-program yang telah direncanakan dalam RKAT (Rencana Kerja Anggaran Tahunan). Pada saat penerimaan dana ZIS tersebut kasir sekaligus bagian perencanaan dan pelaporan memasukkan nominal setoran dan datanya ke dalam aplikasi SIMBA dan mencetak bukti setorannya. Selain menggunakan aplikasi SIMBA kasir juga merekap kas masuk ke dalam buku jurnal pelaporan secara manual. Begitu pula pada saat penyaluran atau pendistribusian dana ZIS. Pada saat dana disalurkan kepada asnaf yang ditentukan melalui program-program yang telah direncanakan dalam RKAT, bagian kasir juga akan melakukan pencatatan dalam aplikasi SIMBA dan juga merekapnya ke dalam buku jurnal pelaporan. Setiap 10 hari sekali jurnal pelaporan tersebut akan di setorkan kepada bagian keuangan yang berwenang dalam membuat laporan, untuk BAZNAS Kabupaten Tulungagung disini adalah Ibu Astri selaku bagian perencanaan dan pelaporan keuangan.

Kemudian setelah menerima setoran tiap 10 hari sekali tersebut, bagian keuangan tersebut akan merekap kedalam Microsoft Excel untuk dibuatnya laporan keuangan bulanan. Laporan keuangan bulanan ini berupa rincian transaksi 
penerimaan dan penyaluran dana ZIS. Setelah pembuatan laporan bulanan tersebut, bagian keuangan juga akan membuat rincian penerimaan dan penyaluran untuk tiap 3 bulan yang akan diserahkan kepadan UPZ sebagai bentuk transparasi BAZNAS. Laporan Keuangan bulanan tersebut selanjutnya akan digabungkan dan disesuaikan untuk dijadikan laporan keuangan tahunan yang kemudian diaudit oleh KAP.

\section{Kesesuaian Perlakuan Akuntansi Zakat, Infak Dan Sedekah BAZNAS Kabupaten Tulungagung Dengan PSAK 109}

Penerimaan dana zakat, infak dan sedekah pada BAZNAS Tulungagung berasal dari beberapa instansi maupun dari muzaki dan munfik individu. BAZNAS Kabupaten Tulungagung memisahkan jurnal atau pencatatan penerimaan atau penghimpunan dana zakat dengan penerimaan atau penghimpunan dana infak. Pengalokasian penyaluran dana ZIS pada BAZNAS Kabupaten Tulungagung adalah berdasarkan program, yang mana pengalokasian atau penyaluran dana ZIS tersebut adalah kepada 8 asnaf. BAZNAS Kabupaten Tulungagung mengakui adanya dana amil dalam bentuk dana operasional. BAZNAS Kabupaten Tulungagung selaku amil juga harus melakukan penjurnalan terkait dengan pengeluaran operasionalnya. Pengakuan dan pengukuran BAZNAS Kabupaten Tulungagung telah sesuai dengan PSAK 109 dimana penerimaan dan penyaluran dana ZIS disesuaikan dengan jenis dananya seperti dana untuk mustahik, amil, dan operasional. Dari paparan mengenai pengakuan dan pengukuran tersebut maka peneliti menganalisa kembali apakah benar dari sisi pengakuan dan pengukuran BAZNAS telah sesuai dengan PSAK 109. Berkaitan dengan hal tersebut peneliti membuat tabel ilustrasi pada Tabel 3.

Tabel 3 Kesesuaian Pengakuan Dan Pengukuran

\begin{tabular}{|c|c|c|}
\hline PSAK 109 & BAZNAS KAB TA & Kesesuaian \\
\hline $\begin{array}{l}\text { Penerimaan zakat diakui pada saat kas } \\
\text { atau aset nonkas diterima. Zakat yang } \\
\text { diterima dari muzaki diakui sebagai } \\
\text { penambah zakat sebesar jumlah yang } \\
\text { diterima jika dalam bentuk kas dan } \\
\text { nilai wajar jika dalam bentuk nonkas. } \\
\text { Penentuan nilai wajar aset nonkas yang } \\
\text { diterima menggunakan harga pasar. }\end{array}$ & $\begin{array}{l}\text { Dana zakat yang telah diterima diakui } \\
\text { sebagai penambah dana sebesar } \\
\text { jumlah dana zakat yang diterima pada } \\
\text { saat kas diterima (BAZNAS TA } \\
\text { tidak, menerima zakat dalam bentuk } \\
\text { non kas/ kecuali zakat fitrah beras } \\
\text { akan disetaran dengan harga pasar). } \\
\text { Zakat fitrah bukan merupakan bagian } \\
\text { dari aset kelolaan. }\end{array}$ & Sesuai \\
\hline $\begin{array}{l}\text { Infak/sedekah yang diterima diakui } \\
\text { sebagai penambah dana infak/sedekah } \\
\text { terikat atau tidak terikat sesuai dengan } \\
\text { tujuan pemberi infak/sedekah sebesar: } \\
\text { a) jumlah yang diterima, jika dalam } \\
\text { bentuk kas ; b) nilai wajar jika dalam } \\
\text { bentuk non kas }\end{array}$ & $\begin{array}{l}\text { Dana infak/ sedekah diakui sebagai } \\
\text { penambah dana infak/sedekah sebesar } \\
\text { jumlah yangditerima pada saat kas } \\
\text { diterima }\end{array}$ & Sesuai \\
\hline $\begin{array}{l}\text { Zakat yang disalurkan } \\
\text { mustahik, termasuk amil, diakui } \\
\text { sebagai pengurang dana zakat sebesar: } \\
\text { jumlah yang diterima, jika dalam } \\
\text { bentuk kas dan nilai wajar, jika dalam } \\
\text { bentuk nonkas }\end{array}$ & $\begin{array}{l}\text { Dana zakat yang telah disalurkan } \\
\text { diakui sebagai pengurang dana zakat } \\
\text { pada saat kas dikeluarkan }\end{array}$ & Sesuai \\
\hline
\end{tabular}


Penyaluran dana infak/sedekah diakui sebagai pengurang dana infak/sedekah sebesar jumlah yang diserahkan, jika dalam bentuk kas dan sebesar nilai tercatat aset yang diserahkan, jika dalam bentuk aset nonkas

Bagian dana zakat dan infak/sedekah yang disalurkan untuk amil diakui sebagai penambah dan amil.
Dana infak/sedekah yang telah
disalurkan diakui $\begin{aligned} & \text { sebagai } \\ & \text { pengurang dana infak/sedekah }\end{aligned}$

pada saat dana dikeluarkan

Sesuai

Bagian ZIS yang disalurkan untuk amil diakui sebagai penambah dana amil namun dalam bentuk dana operasional bersama dengan dana non Sesuai halal.

Penentuan jumlah atau BAZNAS Kab TA menetukan bagian
persentasebagian untuk masing-masing masing-masing mustahik dan munfik mustahik dan munfik ditentukan oleh disesuaikan dengan prinsip syariah, amil sesuai dengan prinsip syariah, kewajaran, etika, dan ketentuan yang berlaku yang dituangkan dalam bentuk kebijakan amil. kewajaran, etika dan dengan sebijakbijaknya mengacu pada programprogram yang telah disepakati pada RKAT. BAZNAS mengambil $20 \%$ dari perolehan infak/sedekah tiap bulan untuk menutup dana operasional. Presentasi penyaluran kepada amil dari dana zakat adalah sebesar 2,5\% dari perolehan dana zakat setahun.

Sumber: Data olahan

Berdasarkan ilustrasi Tabel 3 tersebut, dapat dikatakan bahwa BAZNAS Kabupaten Tulungagung dalam pengakuan dan pengukuran transaksi zakat, infak dan sedekah telah sesuai dengan PSAK 109 sekaligus disesuaikan dengan kondisi dan kebijakan BAZNAS Kabupaten Tulungagung. Tabel 4 merupakan laporan posisi keuangan BAZNAS Kabupaten Tulungagung.

Tabel 4 Neraca BAZNAS Kabupaten Tulungagung Per 31 Desember 2019

\begin{tabular}{lr}
\hline Keterangan & Dalam Rupiah \\
\hline ASET & \\
\hline Aset Lancar & 89.079 .650 \\
Kas dan bak & 0 \\
Piutang lain-lain & 0 \\
Uang muka & $\mathbf{8 9 . 0 7 9 . 6 5 0}$ \\
Jumlah Aset Lancar & 0 \\
Aset Tidak Lancar & 0 \\
Aset Tetap & 0 \\
$\quad$ Inventaris & $\mathbf{0}$ \\
$\quad$ Akumulasi Penyusutan & \\
Jumlah Aset Tidak Lancar & $\mathbf{8 9 . 0 7 9 . 6 5 0}$ \\
TOTAL ASET & 0 \\
Kewajiban Lancar & \\
Hutang Bank & $\mathbf{5 5 . 3 5 5 . 7 7 0}$ \\
Aset Bersih & 17.992 .570 \\
Dana Zakat & $\mathbf{8 9 . 7 3 1 . 3 1 0}$ \\
Dana Infaq dan shodaqoh & $\mathbf{8 9 . 0 7 9 . 6 5 0}$ \\
Dana Operasional & \\
Jumlah Aset Bersih & \\
TOTAL KEWAJIBAN DAN ASET BERSIH & \\
\hline
\end{tabular}

Sumber: BAZNAS Kabupaten Tulungagung 
Berdasarkan Tabel 4, BAZNAS Kabupaten Tulungagung masih menggunakan istilah Laporan Neraca pada Laporan posisi keuangannya. Di dalam laporan posisi keuangannya, BAZNAS Kabupaten Tulungagung telah menyajikan aset lancar dan aset tetap, namun nominal yang tertera pada aset tetap sebesar 0 dikarenakan BAZNAS Kabupaten Tulungagung memperoleh fasilitas pinjaman dari Pemerintah Daerah Kabupaten Tulungagung untuk menggunakan sarana prasarana bangunan dan kendaraan milik Kabupaten Tulungagung berdasarkan surat perjanjian pinjam pakai. Untuk liabilitas, BAZNAS Tulungagung menyajikan hutang bank dengan nominal 0. Sedangkan untuk saldo dananya, BAZNAS Kabupaten Tulungagung sudah memisahkan penyajian antara dana zakat dan dana infak. Namun belum menyajikan dana amil. Dana amil disini disajikan bersama dengan dana non halal dengan istilah dana operasional.

Pada laporan perubahan dana ZIS, amil menyajikan penerimaan, penyaluran, dan penggunaaan dana pada periode tertentu sesuai dengan karakteristiknya sehingga harus disajikan secara terpisah. Tabel 5 merupakan laporan perubahan dana ZIS BAZNAS Kabupaten Tulungagung.

Tabel 5 Laporan Perubahan Dana BAZNAS Kabupaten Tulungagung Untuk Tahun Yang Berakhir Pada Tanggal 31 Desember 2019

\begin{tabular}{|c|c|}
\hline Keterangan & $\begin{array}{l}\text { Dalam } \\
\text { Rupiah }\end{array}$ \\
\hline \multicolumn{2}{|l|}{ DANA ZAKAT } \\
\hline \multicolumn{2}{|l|}{ Penerimaan } \\
\hline \multicolumn{2}{|l|}{ Penerimaan dari muzakki } \\
\hline muzakki individual & 2.116.277.738 \\
\hline \multicolumn{2}{|l|}{ Hasil penempatan } \\
\hline Jumlah penerimaan & 2.116.277.738 \\
\hline \multicolumn{2}{|l|}{ Penyaluran } \\
\hline Tulungagung Makmur Ekonomi Program Zakat Community Development & 100.000 .000 \\
\hline Tulungagung Makmur Ekonomi Program pelatihan Usaha bisnis online & 10.000 .000 \\
\hline TA Cerdas Pend. Program besiswa pend. Santunan Pend. SD/MI & 125.000 .000 \\
\hline TA Cerdas Pend. Program beasiswa pend. Santunan Pend. SMP/MTs & 100.000 .000 \\
\hline TA Cerdas Pendidikan Program besiswa pend. Santunan Pend. SMA/MA & 75.000 .000 \\
\hline TA Cerdas Pend Program Bantuan Satu Keluarga Satu Sarjana 20 Mahasiswa & 220.000 .000 \\
\hline Tulungagung Sehat Program Bantuan Peralatan dan Obat- Obatan Pokestren & 80.000 .000 \\
\hline Tulungagung Sehat Program Khitanan Masal & 63.000 .000 \\
\hline $\begin{array}{l}\text { Tulungagung Taqwa Program pelayanan Dakwah Bantuan Pemb masjid/ } \\
\text { Mushola/ Madin }\end{array}$ & 337.100 .000 \\
\hline Tulungagung Peduli Peogram kemanuasiaan Bantuan Biaya Hidup Fakir & 734.400 .000 \\
\hline Tulungagung Peduli Program kemanusian bantuan yatim & 77.219 .000 \\
\hline Amil & 274.155 .915 \\
\hline Jumlah penyaluran & 2.195 .874 .915 \\
\hline Surplus (defisit) & (79.697.177) \\
\hline Saldo awal & 134.952.947 \\
\hline Saldo akhir & $\mathbf{5 5 . 3 5 5 . 7 7 0}$ \\
\hline \multicolumn{2}{|l|}{ DANA INFAK/SEDEKAH } \\
\hline \multicolumn{2}{|l|}{ Penerimaan } \\
\hline Infak/sedekah terikat dari BAZNAS Jatim & 38.000 .000 \\
\hline Infak/sedekah tidak terikat & 457.802 .700 \\
\hline Infak/sedekah terikat Donasi Bantuan Bencana Alam Lombok & 174.755 .000 \\
\hline Infak/sedekah terikat Donasi Bantuan Bencana Alam Donggala & 300.205 .600 \\
\hline Infak/sedekah terikat Donasi Khitanan massal & 19.900 .000 \\
\hline Hasil pengelolaan & \\
\hline
\end{tabular}


Jumlah penerimaan

Penyaluran

TA Makmur Ekonomi program pemberdayaan ekonomi modal usaha

Tulungagung Cerdas Bantuan Biaya Pendidikan

Tulungagung Sehat Bantuan biaya pengobatan

Tulungagung Taqwa Bantuan Sertifikasi Tanah Wakaf

Tulungagung Taqwa Bantuan Kegiatan Syiar Islam

Tulungagung Taqwa Santunan Yatim Piatu / Dhuafa

Tulungagung Peduli Program bantuan renovasi RTLH

Tulungagung Peduli program bantuan ibnu sabil

Tulungagung Peduli program Bantuan kebencanaan

Tulungagung Peduli program Bantuan kebencanaan

Operasional Kantor BAZ

Tulungagung Peduli Infaq terikat BAZNAS Jatim untuk Fakir miskin

Pinjaman operasional

Tulungagung Peduli Infaq terikat Donasi Khitanan Massal

Alokasi pemanfaatan aset kelolaan (misalnya beban peny.penyisihan)

Jumlah penyaluran

Surplus (defisit)

Saldo awal

Saldo akhir

DANA ZAKAT FITRAH

Penerimaan

muzakki individual

Jumlah penerimaan

Penyaluran

Fakir Miskin

Sabilillah

Amil

Jumlah penyaluran

Surplus (defisit)

Saldo awal

Saldo akhir

DANA OPERASIONAL

SUMBER DANA

Bantuan APBD

Alokasi operasional dari dana infaq $17 \%$

Jasa bank (Zakat, Infak, Pk- 5 dan Operasional Bank Jatim)

Jasa bank (Zakat, Infak, Pk- 5 dan Operasional PD. BPR)

Pinjaman Pihak ke 3

Jumlah penerimaan

PENGGUNAAN DANA

Biaya pegawai

Biaya Adm dan Umum

Biaya publikasi dan dokumentasi

Jumlah penyaluran

Surplus (defisit)

Saldo awal

Saldo akhir

Jumlah saldo dana zakat, dana infak/sedekah

Sumber: BAZNAS Kabupaten Tulungagung
990.663 .300

64.000 .000

20.000 .000

11.500 .000

25.000 .000

85.925 .000

74.839 .000

63.000 .000

1.091 .507

10.000 .000

474.960 .600

73.158 .350

38.000 .000

14.800 .260

19.900 .000

976.174 .717

14.488.583

3.503987

17.992.570

612.355 .500

612.355 .500

535.469 .880

76.885 .620

612.355.500

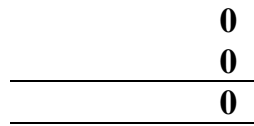

150.000 .000

73.158 .350

1.177 .301

5.170 .071

28.420 .260

257.925 .982

126.000.000

111.653 .823

7.820 .000

245.473 .823

12.452.159

3.279.151

15.731 .310

89.079.650

Berdasarkan Tabel 5, BAZNAS Kabupaten Tulungagung menyajikan penerimaan dana menurut sumber penerimaan dan jenis klasifikasi sumber penerimaan dana baik zakat maupun infak/sedekah. Dalam penyalurannya, BAZNAS Kabupaten Tulungagung menyajikan dana berdasarkan program 
kerjanya yang mengacu kepada 8 asnaf. BAZNAS Kabupaten Tulungagung tidak membuat rincian program mana saja yang masuk ke kriteria dari 8 asnaf tersebut. Sedangkan di dalam laporan keuangan Amil PSAK 109 dana ZIS disalurkan berdasarkan asnafnya, untuk rincian program kerja masuk kedalam kriteria asnaf yang mana dicantumkan dalam catatan atas laporan keuangan.

Berdasarkan hasil observasi dilapangan, kriteria asnaf di BAZNAS Tulungagung beserta programnya yaitu untuk: (1) Fakir miskin, BAZNAS Kabupaten Tulungagung menggabungkan antara asnaf fakir dan amil. Untuk kriterian fakir miskin yang diberikan adalah mengacu kepada Badan Pusat Statistik; (2) Amil, menerima 2,5\% dari keseluruhan jumlah dana zakat satu tahun yang akan disalurkan ke amil UPZ dan dapat juga digunakan untuk menutup biaya operasional; (3) Muallaf, yang besaran dana zakat yang akan disalurkan semua diatur dalam RKAT. Untuk muallaf di Kabupaten Tulungagung sangat kecil presentasinya atau sangat jarang. Sehingga penyalurannya hampir tidak ada; (4)Riqab, BAZNAS Kabupaten Tulungagung belum pernah menemukan asnaf golongan ini. (5) Sabilillah, berupa bantuan keagamaan, syaratnya harus mengajukan proposal ke BAZNAS Kabupaten Tulungagung dan belum menerima bantuan BAZNAS Kabupatenn Tulungagung dalam kurun waktu 3 tahun terakhir; (6) Gharimin, dalam SOP kriteria gharimin yaitu yang dapat membuktikan utangnya untuk kemaslahatan umat dan telah diverifikasi kepada BAZNAS Kabupaten Tulungagung dan harus mengajukan proposal; (7) Ibnu Sabil, untuk ibnu sabil di Tulungagung masih sangat jarang.

Laporan arus merupakan laporan yang mengggambarkan transaksi kas dan setara kas amil zakat, baik kas masuk maupun kas keluar sehingga dapat diketahui kenaikan dan penurunan kas kerdasarkan aktivitas operasi, investasi, maupun pendanaan. Tabel 6 merupakan laporan arus kas BAZNAS Kabupaten Tulungagung.

Tabel 6 Laporan Arus Kas BAZNAS Kabupaten Tulungagung Untuk Tahun Yang Berakhir Pada Tanggal 31 Desember 2019

\begin{tabular}{lr}
\hline \multicolumn{1}{c}{ Keterangan } & \multicolumn{1}{c}{ Dalam Rupiah } \\
\hline ARUS KAS DARI (UNTUK) AKTIVITAS OPERASI & \\
Penerimaan : & 2.116 .277 .738 \\
Penerimaan Zakat & 990.663 .300 \\
Penerimaan Infaq & 257.925 .982 \\
Penerimaan lain-lain Operasional & 3.364 .867 .020 \\
Jumlah Penerimaan & \\
Pengeluaran & 2.195 .874 .915 \\
Pentsyarufan Zakat & 976.174 .717 \\
Pentsyarufan Infaq & 245.473 .823 \\
$\quad$ Beban Operasional & 3.417 .523 .455 \\
Jumlah Pengeluaran & $(52.656 .435)$ \\
Jumlah Kas Diperoleh dari (digunakan untuk) aktivitas operasi & $(52.656 .435)$ \\
KENAIKAN (PENURUNAN) BERSIH KAS \& SETARA KAS & 141.736 .085 \\
KAS DAN SETARA KAS AWAL TAHUN & $\mathbf{8 9 . 0 7 9 . 6 5 0}$ \\
KAS DAN SETARA KAS AKHIR TAHUN & \\
KAS DAN SETARA KAS AKHIR TAHUN & 951.813 \\
Kas & 88.127 .837 \\
\hline Penempatan Pada Bank Lain & $\mathbf{8 9 . 0 7 9 . 6 5 0}$ \\
\hline JUMLAH KAS DAN SETARA KAS & \\
\hline Sumber: BAZNAS Kabupaten Tulungagung &
\end{tabular}


Berdasarkann Tabel 6, BAZNAS Kabupaten Tulungagung menyajikan laporan arus kas berupa aktivitas operasi. Aktivitas operasi ini berasal dari penerimaan dan pengeuaran dana zakat dan infak/sedekah. Untuk kas dan setara kas akhir tahun memiliki dua bentuk yaitu dalam bentuk kas dan kas di bank. (a) Laporan perubahan aset kelolaan, BAZNAS Kabupaten Tulungagung tidak membuat laporan perubahan aset kelolaan, dikarenakan staf pada bidang perencanaan keuangan dan pelaporan kesulitan dalam memasukkan penyusutan aset kelolaan ZIS. Namun untuk laporan perubahan aset kelolaan tercantum dalam laporan keuangan tahunan hasil audit atas rekomendasi dan bantuan dari pihak auditor dari KAP. (b) Catatan atas laporan keuangan, berdasarkan analisis mengenai penyajian laporan keuangan BAZNAS Kabupaten Tulungagung tersebut, diilustrasikan kesesuaian penyajian pada Tabel 7.

Tabel 7 Kesesuaian Penyajian

\begin{tabular}{|c|c|c|}
\hline PSAK 109 & BAZNAS Kabupaten Tulungagung & Kesesuaian \\
\hline $\begin{array}{l}\text { Amil menyajikan dana zakat, } \\
\text { dana infak/sedekah, dan dana } \\
\text { amil secara terpisah dalam } \\
\text { laporan posisi keuangan }\end{array}$ & $\begin{array}{l}\text { Dalam penyajian laporan keuangannya } \\
\text { BAZNAS Kab TA telah menyajikan dana } \\
\text { zakat dan dana infak secara terpisah. Namun } \\
\text { BAZNAS Kabupaten Tulungagung dalam } \\
\text { penyajiannnya menggabung dana amil dan } \\
\text { dana non halal dengan istilah dana } \\
\text { operasional }\end{array}$ & Tidak Sesuai \\
\hline
\end{tabular}

Sumber: Data olahan

Berdasarkan hasil ilustrasi Tabel 7, dapat dikatakan bahwa penyajian laporan keuangan BAZNAS Tulungagung belum sepenuhnya sesuai PSAK 109. Hal ini dikarenakan pada laporan posisi keuangan, BAZNAS Kabupaten Tulungagung telah menyajikan dana zakat dan dana infak secara terpisah. Namun BAZNAS Kabupaten Tulungagung belum memisahkan antara dana amil dengan dana non halal. BAZNAS Kabupaten Tulungagung menggunakan istilah dana operasional untuk kedua dana tersebut.

Dalam PSAK 109 dijelaskan beberapa pengungkapan terkait dengan transaksi-transaksi ZIS. Hal ini berfungsi dalam menunjukkan informasi tambahan yang belum teridentifikasi secara jelas dalam laporan keuangan yang disajikan. Pengungkapan mengenai zakat, infak dan sedekah yang dilakukan BAZNAS dalam penyajian laporan keuangannya diilustrasikan dalam Tabel 8.

Tabel 8 Kesesuaian Pengungkapan

\begin{tabular}{llll}
\hline \multicolumn{2}{c}{ PSAK 109 } & \multicolumn{1}{c}{ BAZNAS Kabupaten Tulungagung } & Kesesuaian \\
\hline $\begin{array}{l}\text { Kebijakan penyaluran zakat } \\
\text { dan infak/sedekah seperti }\end{array}$ & $\begin{array}{l}\text { BAZNAS Kab TA dalam menyakurkan dana } \\
\text { zakat memiliki prioritas dalam menyalurkan }\end{array}$ & \\
penentuan skala prioritas & dananya, yaitu hanya kepada 8 asnaf, fakir & \\
penyaluran, dan mustahik & miskin, amil, fisabilillah dan lainnya, & Sesuai \\
nonamil serta penerima & $\begin{array}{l}\text { disalurkan dalam bentuk program-program } \\
\text { infak/sedekah. }\end{array}$ & yang besaran dananya disepakati pada & \\
& RKAT & & \\
\hline
\end{tabular}




\begin{tabular}{|c|c|c|}
\hline $\begin{array}{l}\text { Kebijakan penyaluran zakat } \\
\text { dan infak sedekah untuk amil } \\
\text { dan mustahik nonamil, seperti } \\
\text { persentase pembagian, alasan, } \\
\text { dan konsistensi kebijakan. }\end{array}$ & $\begin{array}{l}\text { BAZNAS Kab TA mengambil bagian amil } \\
\text { untuk disalurkan ke amil UPZ sebanyak } \\
\text { 2,5\% dari perolehan zakat setahun. Selain itu } \\
\text { BAZNAS Kab TA juga menyalurkan dana } \\
\text { amil sebesar 20\% dari perolehan } \\
\text { infak/sedekah sebulan untuk menutup biaya } \\
\text { operasional. }\end{array}$ & Sesuai \\
\hline $\begin{array}{l}\text { Metode penentuan nilai wajar } \\
\text { yang digunakan untuk } \\
\text { penerimaan zakat berupa aset } \\
\text { nonkas. }\end{array}$ & $\begin{array}{l}\text { BAZNAS Kab TA melakukan peneimaan } \\
\text { hanya berbentuk kas. Kecuali zakat fitrah } \\
\text { beras disetarakan dengan harga pasar pada } \\
\text { saat itu walapupun zakat fitrah bukan bagian } \\
\text { dari aktivitas pengelolaan }\end{array}$ & Sesuai \\
\hline $\begin{array}{l}\text { Rincian jumlah penyaluran } \\
\text { dana zakat dan infak/sedekah } \\
\text { untuk masing - masing } \\
\text { mustahik. }\end{array}$ & $\begin{array}{l}\text { BAZNAS Kab TA dalam menyajikan rincian } \\
\text { penyaluran dana zakat dan infak sedekah } \\
\text { berdasarkan program kerja yang disepakati } \\
\text { RKAT, tanpa penjelasan program tersebut } \\
\text { masuk kriteria asnaf apa. }\end{array}$ & Tidak sesuai \\
\hline $\begin{array}{l}\text { Penggunaan dana zakat dan } \\
\text { infak/sedekah dalam bentuk } \\
\text { aset kelolaan yang masih } \\
\text { dikendalikan oleh amil atau } \\
\text { pihak lain yang kendalikan } \\
\text { amil, jika ada, diungkapkan } \\
\text { jumlah dan persentase } \\
\text { terhadap seluruh penyaluran } \\
\text { dana zakat serta alasannya. }\end{array}$ & $\begin{array}{l}\text { BAZNAS Kabupaten tidak mengelola aset } \\
\text { ZIS dalam waktu yang lama, setiap dana } \\
\text { yang terkumpul akan segera disalurkan } \\
\text { kepada para mustahik. }\end{array}$ & Sesuai \\
\hline $\begin{array}{l}\text { Hubungan pihak-pihak } \\
\text { berelasi antara amil dan } \\
\text { mustahik yang meliputi Sifat } \\
\text { hubungan; Jumlah dan jenis } \\
\text { aset yang disalurkan; } \\
\text { Persentase dari setiap aset } \\
\text { yang disalurkan tersebut dari } \\
\text { total penyaluran zakat selama } \\
\text { periode. }\end{array}$ & $\begin{array}{l}\text { Penerimaan dana BAZNAS Kab TA } \\
\text { bersumber dari zakat pribadi yaitu para PNS } \\
\text { wilayah Kab TA. Selain itu juga berasal dari } \\
\text { hibah baik dari pemerintah (APBD) maupun } \\
\text { yang lainnya, kemudian juga berasal dari } \\
\text { bagi hasil bank syariah dan jasa giro. Dana } \\
\text { yang disalurkan berupa dana zakat dan } \\
\text { infak/sedekah yang terkumpul terutama dari } \\
\text { zakat PNS sebesar 2,5\% dari total gaji } \\
\text { setahun. }\end{array}$ & Sesuai \\
\hline
\end{tabular}

Sumber: Data olahan

Berdasarkan Tabel 8, dapat diketahui bahwa penyajian laporan keuangan BAZNAS Kabupaten Tulungagung secara garis besar sesuai dengan PSAK walapun tidak sepenuhnya. Untuk pengungkapan beberapa berasal dari catatan laporan keuangan yang dijelaskan cukup terperinci dan juga dalam rencana RKAT.

Berdasarkan dari analisis wawancara dan observasi, maka terdapat kendala yang dialami oleh BAZNAS Kabupaten Tulungagung dalam menerapkan PSAK 109 yaitu: (1) Kurangnya SDM yang memadai. (2) Kurangnya sosialisasi mengenai PSAK 109. (3) Sistem dari pusat yang masih belum terorganisir dengan baik. (4) Kebingungan dalam mengukur penyusutan aset kelolaan ataupun aset tetap BAZNAS Kabupaten Tulungagung. (5) Penggunaan bank konvensional dalam pengelolaan dana zakat dan infak sedekah.

Berdasarkan kendala yang dialami oleh BAZNAS Kabupaten Tulungagung, maka terdapat solusi yang dapat diberikan yaitu: (1) Meningkatkan kompetensi pegawai BAZNAS Kabupaten Tulungagung melalui keikut sertaan sosialisasi-sosialisasi mengenai PSAK 109. (2) Mendalami penerapan PSAK pada 
lembaga amil melalui litelatur-litelatur yang terpercaya. (3) Melakukan studi banding ke BAZNAS daerah lain untuk saling bertukar pikiran terkait penggunaan PSAK 109. (4) Memaksimalkan penggunaan sistem SIMBA dari BAZNAS pusat ataupun menggunakan alternatif sistem lain yang dapat membantu dalam pencatatan sesuai dengan PSAK 109. (5) Penggunaan Bank Syariah dalam rangka menghindari adanya riba, maysir dan gharar.

\section{KESIMPULAN}

BAZNAS Kabupaten Tulungagung sudah menerapkan PSAK 109 namun tidak sepenuhnya. Kendala yang dialami oleh BAZNAS Kabupaten Tulungagung dalam menerapkan PSAK 109 meliputi kurangnya SDM yang memadai, kurangnya sosialisasi mengenai PSAK 109, sistem dari pusat masih belum terorganisir dengan baik, kebingungan dalam mengukur penyusutan aset kelolaan ataupun aset tetap BAZNAS Kabupaten Tulungagung, Penggunaan bank konvensional dalam pengelolaan dana zakat, infak dan sedekah.

Solusi yang dapat dilakukan beberapa hal yang meliputi peningkatan kompetensi pegawai termasuk dalam pendalaman penguasaan pencatatan akuntansi sesuai PSAK 109 yang bisa dilakukan dengan cara studi literature terpercaya, diklat dan juga melakukan studi banding ke BAZNAS daerah lain untuk saling bertukar pikiran terkait penggunaan PSAK 109. Tentu saja perlu peningkatan optimal terhadap penggunaan SIMBA dari BAZNAS pusat ataupun menggunakan alternatif sistem lain yang dapat membantu dalam pencatatan sesuai dengan PSAK 109 dan penggunaan Bank Syariah dalam rangka menghindari adanya riba, maysir dan gharar.

\section{DAFTAR PUSTAKA}

Abdullah, Naziruddin, Alias Mat Derus, Husam-Aldin Nizar Al-Malkawi. 2015. "The Effectiveness of Zakat in Alleviating Poverty and Inequalities: A Measurement Using a Newly Developed Technique". Humanomics 31 (3): 314-329. https://doi. org/10.1108/H-02-2014-0016.

Al Arif, Mohammad Nur Rianto. 2012. Lembaga Keuangan Syariah Suatu Kajian Teoritis dan Praktis. Bandung: Pustaka Setia.

Anshori, Ghofur Abdul. 2006. Hukum dan Pemberdayaan Zakat, Cetakan Pertama. Yogyakarta: Pilar Media.

Badan Amil Zakat Nasional Republik Indonesia. 2019. Peraturan Badan Amil Zakat Nasional Republik Indonesia Nomor 1 Tahun 2019 Tentang Tata Cara Pengangkatan Dan Pemberhentian Pimpinan Badan Amil Zakat Nasional Provinsi Dan Pimpinan Badan Amil Zakat Nasional Kabupaten/Kota.

Badan Amil Zakat Nasional. 2020. Profil BAZNAS. Diakses dari halaman web: https://baznas.go.id/profil.

Bupati Tulungagung. 2014. Salinan Surat Keputusan Bupati Tulungagung Nomor: 188.45/183/013/2014 Tentang Badan Amil Zakat Nasional (BAZNAS) Kabupaten Tulungagung.

Djamal, M. 2015. Paradigma Penelitian Kualitatif. Yogyakarta: Pustaka Pelajar. 
Fryanti, Yunida Een. 2018. Akuntansi Lembaga Zakat dan Wakaf. Yogyakarta: Pustaka Pelajar.

Ikatan Akuntan Indonesia. 2007. Pernyataan Standar Akuntansi Keuangan Nomor 101. Jakarta: Dewan Standar Ikatan Akuntan Indonesia.

Ikatan Akuntan Indonesia. 2011. Pernyataan Standar Akuntansi Keuangan Nomor 109. Jakarta: Dewan Standar Ikatan Akuntan Indonesia.

Ikatan Akuntan Indonesia. 2019. SAK Standar Akuntansi Keuangan Syariah Per 1 Januari 2019. Jakarta: Dewan Standar Ikatan Akuntan Indonesia.

Kementerian Agama Republik Indonesia. 2012. Profil Lembaga Pengelola Zakat. Jakarta: Direktorat Jenderal Bimbingan Masyarakat Islam Direktorat Pemberdayaan Zakat.

Khasanah, Umrotul. 2010. Manajemen Zakat Modern Instrumen Pemberdayaan Ekonomi Umat. Malang: UIN-Maliki Press.

Kurniasari, Wiwin. 2011. "Transparansi Pengelolaan Masjid Dengan Laporan Keuangan Berdasarkan Pernyataan Standar Akuntansi Keuangan (PSAK 45). MUQTASHID: Jurnal Ekonomi dan Perbankan Syariah 2 (1): 135152. https://doi.org/10.18326/muqtasid.v2i1.135-152.

Mansour, Walid, Khoutem Ben Jedidia, and Jihed Majdoub. 2015. "How Ethical is Islamic Banking in the Light of the Objectives of Islamic Law?". Journal of Religious Ethics 43 (1): 51-77. https://doi.org/10.1111/jore.12086.

Muchlis, Saiful, and Anna Sutrisna Sukirman. 2016. "Implementasi Maqashid Syariah dalam Corporate Social Responsibility di PT Bank Muamalat Indonesia". Jurnal Akuntansi Multiparadigma 7 (1): 120-130. http://dx.doi.org/10.18202/jamal.2016.04.7011.

Muhamat, Amirul Afif, Norlida Jaafar, Hardi Emrie Rosly, Hasman Abdul Manan. 2013. "An Appraisal on the Business Success of Entrepreneurial Asnaf: An Empirical Study on the State Zakat Organization (The Selangor Zakat Board or Lembaga Zakat Selangor) in Malaysia”. Journal of Financial Reporting and Accounting $11 \quad$ (1): 5163. https://doi.org/10.1108/JFRA-03-2013-0012.

Nurhayati, Sri dan Wasilah. 2015. Akuntansi Syariah di Indonesia. Jakarta: Salemba Empat.

Nurhayati, Sri, dkk. 2019. Akuntansi dan Manajemen Zakat. Jakarta: Salemba Empat.

Presiden Republik Indonesia. 2001. Keputusan Presiden Republik Indonesia Nomor 8 Tahun 2001 Tentang Badan Amil Zakat Nasional.

Presiden Republik Indonesia. 2011. Undang-Undang Republik Indonesia Nomor 23 Tahun 2011 Tentang Pengelolaan Zakat.

Rahim, Syamsuri, dan Sahrullah. 2017. "Model Pengelolaan Zakat Perusahaan". Jurnal Akuntansi Multiparadigma 8 (1): 200-215. http://dx.doi.org/10.18202/jamal.2017.04.7049.

Rahman, Taufiq. 2015. "Akuntansi Zakat, Infak dan Sedekah (PSAK 109): Upaya Peningkatan Transparasi dan Akuntabilitas Organisasi Pengelola Zakat (OPZ)". MUQTASID: Jurnal Ekonomi dan Perbankan Syariah 6 (1): 141164. https://doi.org/10.18326/muqtasid.v6i1.141-164. 
Ritonga, Pandapotan. 2017. "Analisis Akuntansi Zakat Berdasarkan PSAK No. 109 Pada Badan Amil Zakat Nasional (BAZNAS) Sumatera Utara". KITABAH: Jurnal Akuntansi Dan Keuangan Syariah 1 (1): 1-19.

Sugiyono. 2019. Metode Penelitian Kuantitatif, Kualitatif, dan R\&D. Bandung: Alfabeta.

Syafe'i, Rachmat. 2001. Fiqh Muamalah. Bandung: Pustaka Setia.

Wahab, Norazlina Abd., and Abdul Rahim Abdul Rahman. 2011. "A Framework to Analyse the Efficiency and Governance of Zakat Institutions". Journal of Islamic Accounting and Business Research 2 (1): 43-62. https://doi.org/10.1108/17590811111129508.

Wahab, Norazlina Abd., Zairy Zainol, and Mahyuddin Abu Bakar. 2017. "Towards Developing Service Quality Index for Zakat Institutions". Journal of Islamic Accounting and Business Research 8 (3): 326-333. https://doi.org/10.1108/JIABR-09-2015-0040.

Wiroso. 2011. Akuntansi Transaksi Syariah. Jakarta: Ikatan Akuntan Indonesia. Yusuf, Muri. 2014. Metode Penelitian. Jakarta: Kencana. 